\title{
The Smart Narrative of a Smart City
}

\author{
Francesco Gonella* \\ Department of Molecular Sciences and Nanosystems, Research Institute for Complexity, Venice Ca' Foscari University, \\ Venice, Italy
}

The current narrative about Smart Cities is flawed on two levels. First, it describes cities whose promise of smartness is highly biased. Second, it neglects to account for the systemic nature of the urban metabolism, as well as the role of the support region of the city (in terms of its resource provision). In this contribution, I propose a short review of the mainstream Smart City narrative elements as presented by influential and authoritative sources, pointing out their detachment from the reality and from the sustainability of cities described by systemic thinking.

Keywords: Smart City, city narrative, ICT, sustainability, complex systems, systems thinking, emergy analysis

\section{INTRODUCTION}

The Smart City (SC) concept has become a leading idea in policy planning for sustainable urban communities. The focus of sustainability at the city scale is motivated by the contribution of urban areas to economic production and greenhouse gas emissions. The socio-economic problems of an ever-increasingly urbanized world are addressed by the United Nations Sustainable Development Goal number 11, "Sustainable Cities and Communities," and in 2013 more than 140 SC projects were already active (Lee et al., 2013). Recently, Joss et al. (2019) presented a study of more than 5,500 cities, showing how the SC discourse has taken place worldwide to achieve a definite global character. The meaning of the term "Smart City" is poorly defined, as it is related to the contextual mindset of the respective communities of scholars. Several reviews about SC definitions and features may be found in the literature, offering a wide range of perspectives (see for example: Komninos, 2011; O'Grady and O'Hare, 2012; Berardi, 2013; Turcu, 2013; Russo et al., 2014; Albino et al., 2015; Bibri, 2018; Deakin and Reid, 2018; Wu et al., 2018; Zhang et al., 2018; Joss et al., 2019; Ulgiati and Zucaro, 2019). The element that seems to be shared by all of the various approaches to city smartness is the application of Information and Communication Technologies (ICT) to basic infrastructural services (Washburn et al., 2010). The European Union (EU), which is particularly active in the field of SCs (see Russo et al., 2014), gives a definition of the SC as "a place where traditional networks and services are made more efficient with the use of digital and telecommunication technologies for the benefit of its inhabitants and business" ${ }^{\text {. Furthermore, the }}$ European Innovation Partnership on Smart Cities and Communities (EIP-SCC) brings together various social and economic actors to study specific aspects of city life and to propose integrated solutions, in which SCs are expected to "use ICT to enhance their livability, workability, and sustainability," thus increasing smart efficiency to allow citizens to live a "culturally vibrant and happy life."

\section{THE NARRATED SMART CITY}

Accepted: 05 December 2019

Published: 20 December 2019

Citation:

Gonella F (2019) The Smart Narrative of a Smart City.

Front. Sustain. Cities 1:9. doi: 10.3389/frsc.2019.00009

The current narratives about smart cities share common keywords that may be divided into two groups. The first group includes: interconnectedness, e-Gov, ICT, data access, competitiveness,

\footnotetext{
${ }^{1}$ https://ec.europa.eu/info/eu-regional-and-urban-development/topics/cities-and-urban-development/city-initiatives/ smart-cities_en
} 
innovation, creative business, entrepreneurship, and smart mobility. And the second: safety, health, smart living, cultural vibrancy, environmental sustainability, and happiness. The first group comprises of technological tools and socio-economic conditions, mostly related to the city itself, while the second group is made up of goals and objectives that are more related to the citizens. While there is a general consensus about the presence of both groups of keywords in a comprehensive modern SC narrative, no mention is made about why and how the tools and operations in the first group should lead to the goals indicated by the second. In the SC narrative, the two groups are often connected with each other, as if ICT-based smartness is necessary and sufficient for the happiness of citizens. Interestingly, this may be true for specific subsets of citizens. Figure 1 shows an aerial photograph taken by the photographer Tuca Vieira in São Paulo, Brazil, showing how complex urban self-organization may lead to two different worlds, separated by a wall. In the upper part of Figure 1, a typical iconic representation of an SC accompanies the photograph. The reality tells us that the smartness icons concern only the right hand side of the photograph. In the SC narrative, real problems that are the root of the "un-smartness" of a city, like poverty, inequality, unemployment, illiteracy, corruption, lack of sanitary and educational structures, are just not addressed whatsoever.

The SC narrative therefore leads to cognitive dissonance, talking of cities that do not exist and are not going to exist. Let's take the example of London. London is reported to be the smartest city in the world, according to the main agencies and institutions that publish the relative rankings, for example the Eden Strategy Institute ${ }^{2}$, the IESE Business School ${ }^{3}$, or the School of Social and Political Sciences of the University of Glasgow (Joss et al., 2019). In these rankings, the smartness of a city is closely linked to its degree of ICT interconnectedness, which is implicitly assumed to well represent the path toward people's happiness and smart living. Similarly, London is the world leader in terms of its smart connection infrastructures, the number of "creative business makers" and its "cultural vibrancy." But official government data from the London Datastore ${ }^{4}$ tells another story. The number of Londoners living in poverty continues to rise, currently standing at about 2.4 million people. This includes 37 percent (around 700,000) of the children living in the London area. According to the CHAIN multi agency database ${ }^{5}$, commissioned and funded by the Mayor of London, almost 9,000 people slept rough in the capital in 2018, with an astonishing growth rate of 15 new homeless per day. In 2018, according to the Sunday Times ${ }^{6}$, London overtook New York City in the murder rate. It is hard to see in these figures the smart living advocated by the SC narrative, unless one considers the richest subset of Londoners as the real and only end-user of this smartness revolution. In most of the world's biggest cities, slum dwellers are

\footnotetext{
${ }^{2}$ https://www.smartcitiesworld.net/news/news/report-ranks- top-50-smart-citieson-leadership-and-governance- 3100

${ }^{3}$ https://www.smartcity.press/top-10-smart-cities-of-2019/

${ }^{4}$ https://data.london.gov.uk

${ }^{5} \mathrm{https}$ //www.mungos.org/combined-homelessness-and-information-network/

${ }^{6}$ https://www.thetimes.co.uk/article/london-murder-rate-beats-new-york-asstabbings-surge-f59w0xqs0
}

constantly increasing. They number about one billion people, and are excluded from any participatory form of city life. For many of them, talking of "smart interconnectedness" where there is no access to electricity or internet access, or of sanitary data where there aren't health services, is just bitterly senseless. "Culturally vibrant" smart living is a secondary problem if the primary one is just that of living. The European Union Smart Cities Information System recently published a report entitled "The making of a smart city: best practices across Europe"7. In its 256 pages, the words "mobility" and "business" appear 114 and 67 times, respectively. The words "children," "poverty," "violence," "disability," "inequality," "welfare," and "homeless" never appear. This clarifies not only the meaning of "smartness" in the EU policy, but also how policy-makers consider their commitment to solve real and serious problems in the cities as something that can be managed separately-as if the two realities of a fully ICT-interconnected and a socially devastated city refer to two different, parallel worlds.

The role of people in the current SC narrative is also quite ambiguous. On one hand, people are called on to become smart, creative, connected, healthy, safe, culturally vibrant, and happy (Florida, 2005; Dirks et al., 2010; Winters, 2011; Alawadhi et al., 2012; Lombardi et al., 2012), though no rationale is provided to explain why and how ICT-based urban infrastructures should make people happy. On the other hand, smart hyperconnected people are expected to create smart business (whatever this means), and -following the example of the European Union ${ }^{8}$ environment of Small-Medium Enterprises (SMEs) that, by means of smart energy, smart transportation and ICT, assures the competitiveness of the city. As addressed by the Industrial Internet of Things (IIoT) association", "Smart city management models must integrate a new ecosystem of value creators and innovators," including "innovative spaces" where people are supported in "monetizing new business models." The mindset of a digitized city where the citizens act as customers is summarized on the World Economic Forum Agenda website ${ }^{10}$ by T. A. Puutio, who ends his article on the future of our cities by stating that: "The time when governments see us as customers rather than citizens may be closer than we imagine. And when it comes, we can be sure to thank digitization." Indeed, this conclusion appears deadly sharp and motivated, with no reason addressed for questioning the appeal of smart cities.

Critics who are against the very idea of SCs are becoming more and more common, because of the concerns about climate changes and integrated sustainability at all levels (Gonella et al., 2019). The attention of urban analysts is drawn to the use of the term "smart city" when referring to strategic platforms of urban development aimed only at economic growth and development (Ballas, 2013; Cugurullo, 2018). By

\footnotetext{
${ }^{7}$ https://www.smartcitiesinfosystem.eu/sites/default/files/document/ the_making_of_a_smart_city_best_practices_across_europe.pdf ${ }^{8}$ http://europa.eu/rapid/pressrelease_MEMO-13-1049_en.htm-an ${ }^{9}$ https://iiot-world.com/

${ }^{10}$ https://www.weforum.org/agenda/2018/02/here-are-5-predictions-for-thecities-of-the-future/
} 


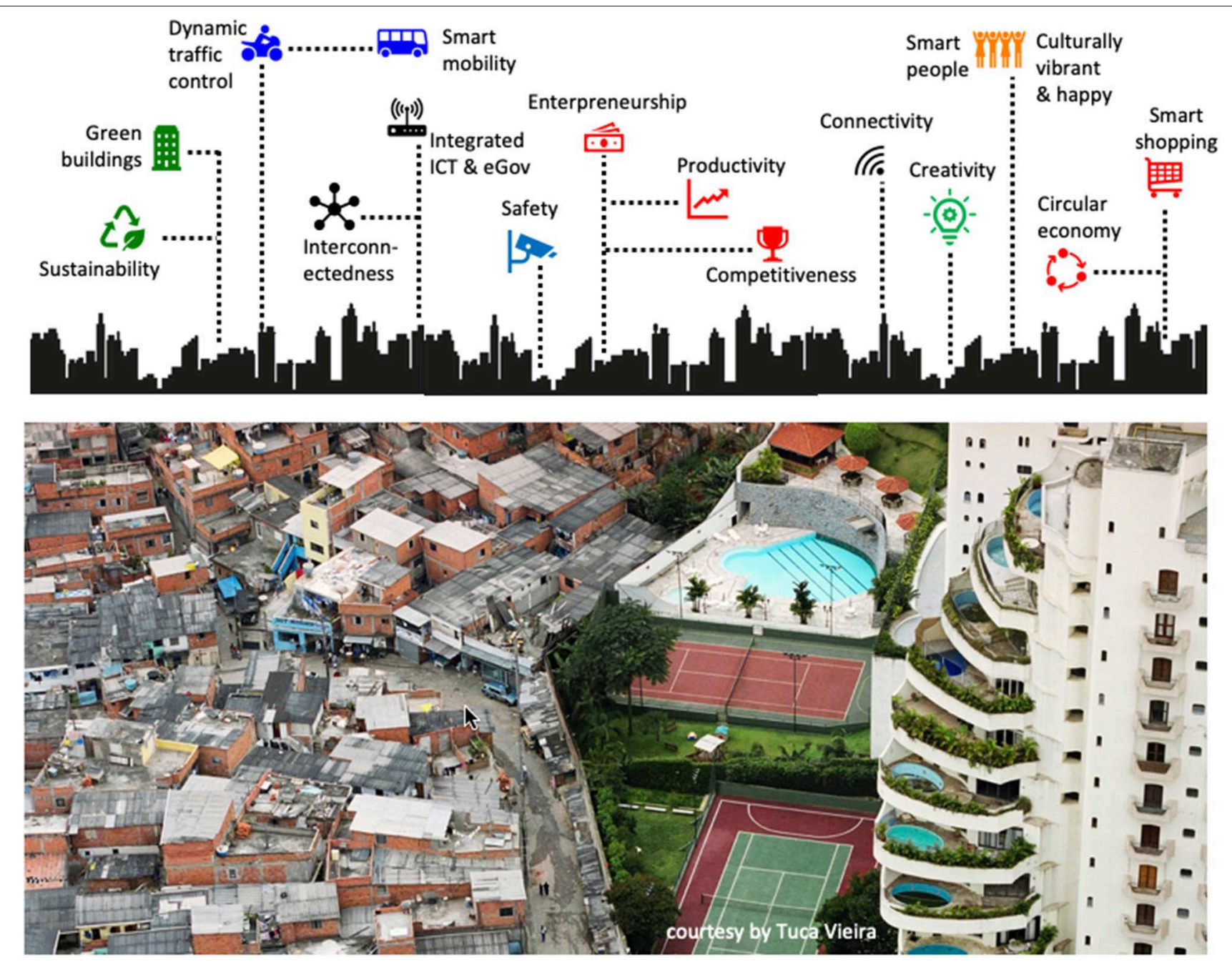

FIGURE 1 | (Upper) An iconic representation of a smart city. (Lower) An aerial photograph of an urban area in São Paulo, Brazil (courtesy by Tuca Vieira).

these analysts, the concept of a SC is seen as heavily biased, describing cities conceived as corporate-designed (Greenfield, 2013) whose smartness consists, essentially, in being rich. The architect Kevin Rogan refers to the SC narrative as "making it look like they're doing something they're not, like making a neighborhood instead of building a huge behavioral data farm" ${ }^{11}$. SCs are therefore seen as part of a technochauvinistic scenario (Broussard, 2019). It appears that the feeling many scientists have from listening to the SCs narrative is that it addresses just one fundamental message: there is money to be made.

\section{THE SYSTEMIC SMART CITY}

The polarized mindset described above makes the SC narrative appear to be detached from reality, but coherent with a

\footnotetext{
${ }^{11}$ https://www.citylab.com/design/2019/06/smart-city-photos-technologymarketing-branding-jibberjabber/592123/
}

technology-based economy based on a (supposedly green) growth framework. Nevertheless, a technical flaw in this narrative makes its supposed effectiveness highly questionable, and this flaw is related to the stunning citizens division created by the wall depicted in Figure 1. This kind of highly structured selforganization derives from the complexity of the city system itself, and is an intrinsic feature that the city exhibits when under certain external driving forces of environmental, economic and social nature. The complex network of feedback that characterizes the flows of resources, information, and money supporting a city is ultimately responsible for the configurations that the city elements may or may not assume. Only a systemic study of the dynamic patterns and leverage points in the feedback network may lead to suitable actions that lead toward real city smartness, and there is no indicator that e-Gov or ICT can be one of these leverage points. The need for a Systems Thinking approach originates from the consideration that complex systems require complex approaches, and that virtually unpredictable systemic structures may develop autonomously depending on 
the network of relationships between the system components (Jackson, 2000; Sterman, 2002, 2012; Meadows, 2008). As sharply pointed out by Orr (2014), the organization of complexity is the bottleneck for achieving smartness of any given kind. As many quantities may vary simultaneously and "in subtly interconnected ways," describing and understanding the city's behavioral patterns requires equally complex approaches, that are also able to connect the resource flows to the supporting environment. As underlined by Kanter and Litow (2009) in their Manifesto for Smarter Cities, making smart each subsystem of a city one after another does not create a smart city, since the city is actually an organic whole. And any innovation process at the urban level must take into account the consequences in the network of inflows of resources provided by the city's supporting area (Ascione et al., 2011; Brown and Ulgiati, 2011). From a systemic point of view, neglecting the SC's surroundings means just shifting the burden of social, environmental and economic problems to somebody else elsewhere. In an illuminating recent article, Herendeen (2019) talks about Burlington, Vermont, the first USA city to become $100 \%$ renewable in electricity. How "smart" is all this? Fairly smart, according to the current narratives. But Burlington's hydroelectricity comes from Québèc, which is $700 \mathrm{~km}$ away. Its wind electricity comes from outside sources, as well as the biomass forestry residues used in burning plants. How much does the infrastructure necessary to convey the electricity to Burlington cost the environment? Maybe a lot, maybe not a lot. To understand this, a systemic awareness is required, and the application of systemic approaches (Gonzalez-Mejía et al., 2012).

Since energy flows are actually the driver of urban activities, the use of energy-referred approaches to quantify the study of city metabolism in all of its aspects appears mandatory. In particular, emergy (spelled with an " $\mathrm{m}$ ") analysis is one promising methodology for quantitative studies (Odum, 1988, 1996, 2007). It is a method that quantifies the overall support to processes, and studies the sustainable patterns for human and ecological integrated systems by describing how complex systems use and organize resources. Emergy (from EMbodied enERGY) is the quantity that accounts for all of the upstream resource contributions-labor and services included-under the same unit. The analysis is based on the setting up of stock-flow diagrams, in which extensive variables (stocks of quantities like mass, energy, people, information, money, and so on) are connected to each other by flows that represent physical flows of mass, energy and information. Figure 2 shows what a generic systemic city diagram looks like. Even without entering any details into the diagram, it allows an appreciation of how the city system operates under quite a complex configuration, where a change in any of the variables represented by the stocks will influence virtually all of the other ones, with time delays that in turn play a role in the system dynamics. This diagram represents a

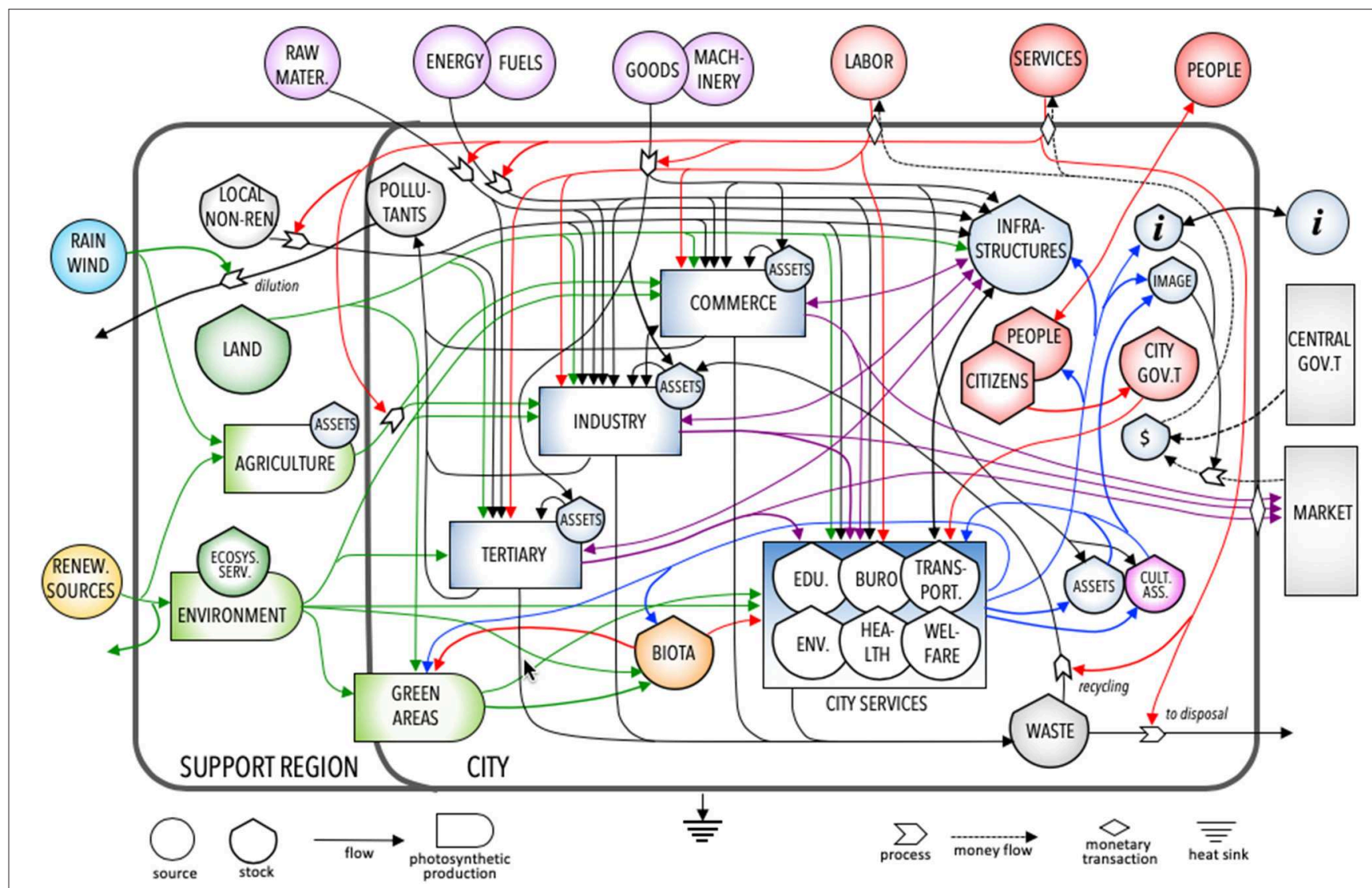

FIGURE 2 | A stock-flow systemic diagram of a generic city, along with its support region, showing the relevant resource flows and the network of feedback between the elements. 
general scheme for a city, and may be used in future works as a conceptual baseline for developing quantitative emergybased simulations focused on particular aspects, for which the diagrammatic description may be further refined. Emergy analysis has already been applied to urban situations (Huang and Chen, 2005; Lei et al., 2008; Ascione et al., 2009). More recently, Liu et al. (2014) developed an emergy-based simulator, with the aim of describing and forecasting the resource flows, the economic pattern and the environmental impacts of Beijing. In that work, the urban performance is described by defining nine proper city subsystems that include-at various levels-land, assets, water, money, and population. The analysis of the city dynamics then proceeds by setting up a system of non-linear relations, determined by the operational feedback network. Further recent works reporting systemic analyses applied to city sustainability are from Viglia et al. (2016), Agostinho et al. (2018), Marvuglia et al. (2018), Lee and Braham (2019), Braham et al. (2019) and Ulgiati and Zucaro (2019), who also link emergy analysis to a circular economy, which is one of the hot topics in the context of urban planning. In particular, Ulgiati and Zucaro explicitly use the notion of urban metabolism (Céspedes Restrepo and Morales-Pinzón, 2018), and for all internal city processes they use a biology-based narrative for the exchange of matter and energy between the living organisms and the environment. This also aims to emphasize that cities are "natural" complex systems, in the sense that they obey the same laws as the rest of nature, in particular, the second principle of Thermodynamics and the maximum (em)power principle (Lotka, 1922; Hall, 2004).

\section{ON SMARTNESS INDICATORS}

Several attempts to classify the smartness of a city from a reductionist point of view are proposed in the literature. City managers and policy makers welcome quantitative indicators (Lazaroiu and Roscia, 2012; Berardi, 2013), among which one should find a variety of aspects of city life that leading city managers can use to monitor the path toward smartness. We can roughly distinguish four groups of city aspects suitable to be measured as indicators. The first includes aspects of a city that are important, but are too generic to be used to address analytical features. To this class belong smart education, sustainable management, well-being, happiness, cultural vibrancy, innovative spirit, and citizen focus. They do not provide analytical contributions, being proposed mainly for the rhetorical purpose of framing measurable actions of city management within an endorsable vision of sustainable happiness. A second class is formed by indicators referred to as the ICT-based aspects, like integrated infrastructures, knowledge sharing, open data, baselines, that are relatively simple to measure and control. As already said, their link to the promise of the above mentioned vision remains unaddressed. A third class is comprised of common-sense aspects that should not need any conceptual framework to be pursued by any city governance, like green and pedestrian areas, pollution and waste production control, recycling, energy efficiency, and so on. A fourth class comprises indicators that are more elusive, often pertaining to the economic dimension: the performance of business models, the level of procurement and funding, the flexibility of the labor market, levels of competitiveness and entrepreneurship, the amount of smart energy use, and so on. Mixing up the four categories is methodologically dangerous, since they are logically separated. In May 2016, the United Nations Economic Commission for Europe (UNECE) launched the United for Smart Sustainable Cities (U4SSC) initiative, releasing a 125-page report entitled "Collection Methodology for Key Performance Indicators for Smart Sustainable Cities." This was drawn up in collaboration with 16 UN Agencies and Institutions, among with the Convention on Biological Diversity (CBD), the Food and Agriculture Organization (FAO), the UN Development Programme (UNDP), the UN Educational, Scientific and Cultural Organization (UNESCO), and the UN Framework Convention for Climate Change (UNFCCC). The report lists as many as 91 "Key Performance Indicators," providing details on how to calculate them and how to get the necessary data. The report states that "Each indicator forms a part of a holistic view of a city's performance in three dimensions; Economy, Environment, and Society and Culture. Each of these dimensions provides a separate view of progress and when reported together provide a holistic view of a smart sustainable city." Unfortunately, this idea of what constitutes a holistic approach is just wrong, from both cultural and scientific perspectives. Ninety-one separate indicators put together do not represent the complexity of the system, since complexity is not rooted in the number of performance parameters, but rather in the network of connections existing between the variables that define these parameters.

\section{CONCLUSIONS}

The mainstream SC narrative as presented by most of the current outlines, especially at the highest institutional level (UN, EU), often talks of an urban reality that does not exist. ICT-based technologies are attributed to a role they cannot have, that of creating a safe, healthy city hosting creative and happy citizens. Economic growth seems to be the mantra dominating the smart city paradigm. However, dynamically stationary states are the intrinsic condition of sustainability toward which a complex selforganizing system should naturally trend, thus indicating that real "smartness" is incompatible with the growth mantra. As far as the city metabolism may be regarded to be a complex system, it appears that the smartness, and more generally the sustainability, of a city can be pursued only by using integrated systemic approaches. They must take into account how all of the elements of the city are related through the urban structural network of feedback, and by the interflows with the support region. In the current SC narrative, this systemic awareness is lacking.

\section{AUTHOR CONTRIBUTIONS}

FG conceived the idea, performed the bibliographic search, developed, and wrote the overall perspective contribution without further collaboration. 


\section{FUNDING}

This paper was realized with the contribution of the Italian Ministry of Foreign Affairs and

\section{REFERENCES}

Agostinho, F., Sevegnani, F., Almeida, C. M. V. B., and Giannetti, B. F. (2018). Exploring the potentialities of emergy accounting in studying the limits to growth of urban systems. Ecol. Indic. 94, 4-12. doi: 10.1016/j.ecolind.2016.05.007

Alawadhi, S., Aldama-Nalda, A., Chourabi, H., Gil-Garcia, J. R., Leung, S., Mellouli, T., et al. (2012). Building understanding of Smart City initiatives. Lect. Notes Comput. Sci. 7443, 40-53. doi: 10.1007/978-3-642-33489-4_4

Albino, V., Berardi, U., and Dangelico, R. M. (2015). Smart cities: definitions, dimensions, performance, and initiatives. J. Urban Technol. 22, 3-21, doi: 10.1080/10630732.2014.942092

Ascione, M., Bargigli, S., Campanella, L., and Ulgiati, S. (2011). Exploring an urban system's dependence on the environment as a source and a sink: the city of rome (Italy) across space and time scales. ChemSusChem 4, 613-627. doi: $10.1002 /$ cssc.201000214

Ascione, M., Campanella, L., Cherubini, F., and Ulgiati, S. (2009). Environmental driving forces of urban growth and development. An emergy-based assessment of the city of Rome, Italy. Landsc. Urban Plann. 93, 238-249. doi: 10.1016/j.landurbplan.2009.07.011

Ballas, D. (2013). What makes a 'Happy City'?. Cities 32, S39-S50. doi: 10.1016/j.cities.2013.04.009

Berardi, U. (2013). Sustainability assessments of urban communities through rating systems. Environ. Dev. Sustain. 15, 1573-1591. doi: $10.1007 /$ s10668-013-9462-0

Bibri, S. E. (2018). Smart Sustainable Cities of the Future - The Untapped Potential of Big Data Analytics and Context-Aware Computing for Advancing Sustainability. The Urban Book Series. Cham: Springer International Publishing AG. doi: 10.1007/978-3-319-73981-6

Braham, W. W., Lee, J. M., Oskierko-Jeznacki, E., Silverman, B., and Khansari, N. (2019). Spatial concentration of urban assets in the Philadelphia region: an emergy synthesis. Ecol. Model. 401, 52-68. doi: 10.1016/j.ecolmodel.2019.03.016

Broussard, M. (2019). Artificial Unintelligence: How Computers Misunderstand the World. Cambridge, MA: The MIT Press.

Brown, M. T., and Ulgiati, S. (2011). Understanding the global economic crisis: a biophysical perspective. Ecol. Model. 223, 4-13. doi: 10.1016/j.ecolmodel.2011.05.019

Céspedes Restrepo, J. D., and Morales-Pinzón, T. (2018). Urban metabolism and sustainability: precedents, genesis and research perspectives. Resour. Conserv. Recycl. 131, 216-224. doi: 10.1016/j.resconrec.2017.12.023

Cugurullo, F. (2018). "The origin of the Smart City imaginary: from the dawn of modernity to the eclipse of reason," in The Routledge Companion to Urban Imaginaries, eds C. Lindner and M. Meissner (London: Routledge), 1-20.

Deakin, M., and Reid, A. (2018). Smart cities: under-gridding the sustainability of city-districts as energy efficient-low carbon zones. J. Cleaner Prod. 173, 39-48. doi: 10.1016/j.jclepro.2016.12.054

Dirks, S., Gurdgiev, C., and Keeling, M. (2010). Smarter Cities for Smarter Growth: How Cities Can Optimize Their Systems for the Talent-Based Economy. Somers, NY: IBM Global Business Services.

Florida, R. (2005). Cities and the Creative Class. New York, NY: Routledge.

Gonella, F., Almeida, C. M. V. B., Fiorentino, G., Handayani, K., Spanò, F., Testoni, R., et al. (2019). Is technology optimism justified? A discussion towards a comprehensive narrative. J. Cleaner Prod. 223, 456-465. doi: $10.1016 /$ j.jclepro.2019.03.126

Gonzalez-Mejía, A. M., Eason, T. N., Cabezas, H., and Suidan, M. T. (2012). Assessing sustainability in real urban systems: the greater cincinnati metropolitan areain Ohio, Kentucky, and Indiana. Environ. Sci. Technol. 46, 9620-9629. doi: 10.1021/es3007904

Greenfield, A. (2013). Against the Smart City. New York, NY: Do Projects.
International Cooperation - Ministero degli Affari Esteri e della Cooperazione Internazionale, Direzione Generale per la Promozione del Sistema Paese (Grant number PGR05278).
Hall, C. A. S. (2004). The continuing importance of maximum power. Ecol. Model. 178, 107-113. doi: 10.1016/j.ecolmodel.2004.03.003

Herendeen, R. (2019). Does " $100 \%$ renewable" trump concern for spatial impacts? Energy Policy 130, 304-310. doi: 10.1016/j.enpol.2019.04.002

Huang, S.-L., and Chen, C.-W. (2005). Theory of urban energetics and mechanisms of urban development. Ecol. Model. 189, 49-71. doi: 10.1016/j.ecolmodel.2005.03.004

Jackson, M. C. (2000). Systems Approaches to Management. New York, NY: Kluwer Academic/Plenum Publisher.

Joss, S., Sengers, F., Schraven, D., Caprotti, F., and Dayot, Y. (2019). The smart city as global discourse: storylines and critical junctures across 27 cities. J. Urban Technol. 26, 3-34. doi: 10.1080/10630732.2018.1558387

Kanter, R. M., and Litow, S. S. (2009). "Informed and interconnected: A manifesto for smarter cities," in Harvard Business School General Management Unit, Working Paper (Boston, MA), 9-141.

Komninos, N. (2011). Intelligent cities: variable geometries of spatial intelligence. Intell. Build. Int. 3, 172-188. doi: 10.1080/17508975.2011.579339

Lazaroiu, G. C., and Roscia, M. (2012). Definition methodology for the Smart Cities model. Energy 47, 326-332. doi: 10.1016/j.energy.2012.09.028

Lee, J. H., Phaal, R., and Lee, S. (2013). An integrated service-device-technology roadmap for Smart City Development. Technol. Forecast. Soc. Change 80, 286-306. doi: 10.1016/j.techfore.2012.09.020

Lee, J. M., and Braham, W. (2019). Right-sizing cities for maximum power: urban form parameters for New York City and the Greater Philadelphia region. Sustainability 11, 2352-2371. doi: 10.3390/su11082352

Lei, K., Wang, Z., and Shanshin, T. (2008). Holistic emergy analysis of Macao. Ecol. Eng. 32, 30-43. doi: 10.1016/j.ecoleng.2007.08.008

Liu, G., Zhifeng Yang, Z., Chen, B., and Ulgiati, S. (2014). Emergy-based dynamic mechanisms of urban development, resource consumption and environmental impacts. Ecol. Model. 271, 90-102. doi: 10.1016/j.ecolmodel.2013. 08.014

Lombardi, P., Giordano, S., Farouh, H., and Yousef, W. (2012). Modelling the Smart City performance innovation. Euro. J. Soc. Sci. Res. 25, 137-149. doi: $10.1080 / 13511610.2012 .660325$

Lotka, A. (1922). Natural selection as a physical principle. Proc. Natl. Acad. Sci. U.S.A. 8, 151-155.

Marvuglia, A., Santagata, R., Rugani, B., Benetto, E., and Ulgiati, S. (2018). Emergybased indicators to measure circularity: promises and problems. Energy Policy J. 21, 179-196. doi: 10.24425/124510

Meadows, D. H. (2008). Thinking in Systems: A Primer. White River Junction, VT: Chelsea Green Publishing.

Odum, H. T. (1988). Self-organization, transformity, and information. Science 242, 1132-1139. doi: 10.1126/science.242.4882.1132

Odum, H. T. (1996). Environmental Accounting, Emergy and Environmental Decision Making. New York, NY: Wiley.

Odum, H. T. (2007). Environment, Power and Society for the Twenty-First Century: The Hierarchy of Energy. New York, NY: Columbia University Press.

O'Grady, M., and O'Hare, G. (2012). How smart is your city?. Science 335, 1581-1582. doi: $10.1126 /$ science. 1217637

Orr, D. (2014). Systems Thinking and the future of cities. Solutions. Available online at: http://www.thesolutionsjournal.com/node/237149

Russo, F., Rindone, C., and Panuccio, P. (2014). The Process of Smart City Definition at an EU Level. WIT Transactions on Ecology and The Environment 191, WIT Press. Available online at: www.witpress.com.

Sterman, J. D. (2002). All models are wrong: reflections on becoming a systems scientist. Syst. Dyn. Rev. 18, 501-531. doi: 10.1002/sdr.261

Sterman, J. D. (2012). "Sustaining Sustainability: Creating a Systems Science in a Fragmented Academy and Polarized World," in Sustainability Science: The Emerging Paradigm and the Urban Environment, M. P. Weinstein and R. E. Turner (New York, NY: Springer), 21-58. 
Turcu, C. (2013). Re-thinking sustainability indicators: local perspectives of urban sustainability. J. Environ. Plann. Manage. 56, 695-719. doi: 10.1080/09640568.2012.698984

Ulgiati, S., and Zucaro, A. (2019). Challenges in urban metabolism: sustainability and well-being in cities. Front. Sustain. Cities 1:1. doi: 10.3389/frsc.2019.00001

Viglia, S., Civitillo, D. F., Cacciapuoti, G., and Ulgiati, S. (2016). Indicators of environmental loading and sustainability of urban systems. An emergy-based environmental footprint. Ecol. Indic. 94, 82-99. doi: 10.1016/j.ecolind.2017.03.060

Washburn, D., Sindhu, U., Balaouras, S., Dines, R. A., Hayes, N. M., and Nelson, L. E. (2010). Helping CIOs Understand "Smart City" Initiatives: Defining the Smart City, Its Drivers, and the Role of the CIO. Cambridge, MA: Forrester Research.

Winters, J. V. (2011). Why are smart cities growing? Who moves and who stays. J. Region. Sci. 51, 253-270. doi: 10.1111/j.1467-9787.2010.00693.x

Wu, Y., Zhang, W., Shen, J., Mo, Z., and Peng, Y. (2018). Smart city with Chinesecharacteristics against the background of big data: idea, action and risk. J. Cleaner Prod. 173, 60-66. doi: 10.1016/j.jclepro.2017 01.047

Zhang, X., Bayulken, B., Skitmore, M., Lu, W., and Huisingh, D. (2018) Editorial - Sustainable urban transformations towards smarter, healthier cities: theories, agendas and pathways. J. Cleaner Prod. 173, 1-10. doi: 10.1016/j.jclepro.2017.10.345

Conflict of Interest: The author declares that the research was conducted in the absence of any commercial or financial relationships that could be construed as a potential conflict of interest.

Copyright (C) 2019 Gonella. This is an open-access article distributed under the terms of the Creative Commons Attribution License (CC BY). The use, distribution or reproduction in other forums is permitted, provided the original author(s) and the copyright owner(s) are credited and that the original publication in this journal is cited, in accordance with accepted academic practice. No use, distribution or reproduction is permitted which does not comply with these terms. 